\title{
Aboriginal Rights in Transition: Reassessing Aboriginal Title and Governance
}

Kent McNeil

Osgoode Hall Law School of York University, kmcneil@osgoode.yorku.ca

Source Publication:

American Review of Canadian Studies. Volume 31, Numbers 1-2 (2001), p. 317-329.

Follow this and additional works at: https://digitalcommons.osgoode.yorku.ca/scholarly_works

Part of the Indian and Aboriginal Law Commons

(c) $(i) \Theta \Theta$

This work is licensed under a Creative Commons Attribution-Noncommercial-No Derivative Works 4.0 License.

\section{Recommended Citation}

McNeil, Kent. "Aboriginal Rights in Transition: Reassessing Aboriginal Title and Governance." American Review of Canadian Studies 31.1/2 (2001): 317-329.

This Article is brought to you for free and open access by the Faculty Scholarship at Osgoode Digital Commons. It has been accepted for inclusion in Articles \& Book Chapters by an authorized administrator of Osgoode Digital Commons. 


\section{Aboriginal Rights in Transition: Reassessing Aboriginal Title and Governance}

\section{KENT McNEIL}

In the past five years, there have been some very significant political and legal developments in relation to the Aboriginal peoples of Canada. On 1 April 1999, Nunavut emerged as a new territory in the central Arctic, under the defacto control of the Inuit residents who comprise about 85 percent of the population. The previous August, the Nisga'a Agreement was initialed in British Columbia after almost twenty-five years of negotiations. This is the first modem landclaims agreement to be signed in a province where most of the land is claimed by Aboriginal peoples by virtue of their Aboriginal title. On 7 January 1998, the Canadian government announced a new policy of reconciliation with the Aboriginal peoples, aimed at strengthening Aboriginal governance and economic development, and healing some of the wounds caused by the tragic legacy of the residential school system. This policy initiative was in partial response to the massive five-volume Report of the Royal Commission on Aboriginal Peoples, released in the fall of 1996, that condemned Canada for its past treatment of the Aboriginal peoples and recommended a fundamental restructuring of the relationship based on principles of mutual recognition, respect, sharing, and responsibility.

These political arrangements and policy initiatives have been matched by equally dramatic developments in the law of Aboriginal rights by the Supreme Court of Canada. In a series of important decisions, the Court has come to 
grips with a number of issues that it did its best to avoid in the past, involving the identification and definition of Aboriginal rights, the content of Aboriginal title to land and the requirements for proving it, and the relevance of the law of New France to Aboriginal rights today. This paper will focus on these recent developments in the law, as well as attempting to identify areas where the law of Aboriginal rights is incomplete and so requires further judicial elucidation.

Constitutionalization of Aboriginal Rights and the "Integral to the Distinctive Culture" Test

Prior to three decisions released by the Supreme Court in August of 1996, which are collectively known as the Van der Peet trilogy, there were no clear legal guidelines for identifying and defining Aboriginal rights. Those rights were generally known to arise from the precolonial presence of Aboriginal societies in Canada and their occupation of lands but, prior to 1996, the Court had not laid down any rules for determining which practices and traditions qualified for protection as Aboriginal rights and which did not. This matter became particularly important when Aboriginal rights were accorded constitutional protection (along with treaty rights, which will not be discussed in this paper) at the same time as the Canadian Charter of Rights and Freedoms was introduced in 1982. This protection was provided by section 35( I ) of the Constitution Act, 1982, which states that "The existing aboriginal and treaty rights of the aboriginal peoples of 
Canada are hereby recognized and affirmed." ${ }^{11}$ The intention was to identify and define Aboriginal rights by political means and, possibly, by further constitutional amendment. But even though four constitutional conferences were held in the 1980s to accomplish this task, the talks foundered over the issue of Aboriginal self-government. As a result, identification and definition of Aboriginal rights were relegated to the legal forum of the courts by default. ${ }^{2}$

The Supreme Court first considered the effect of the constitutionalization of Aboriginal rights in the Sparrow case, decided in $1990 .{ }^{3}$ In that case the right in question-the right of the Musqueam Nation in British Columbia to fish for food, societal, and ceremonial purposes-was accepted by the Court without the need to formulate a test for identification of Aboriginal rights generally. The Court focused instead on the issues of extinguishment and infringement of Aboriginal rights, holding that the rights constitutionalized in 1982 are those that were "existing" in the sense that they had not previously been extinguished by clear and plain legislation or treaty. The Court nonetheless decided that the constitutional protection provided in 1982 is not absolute-Aboriginal rights can still be infringed by legislation if the government can establish a valid legislative objective for the infringement that is substantial and compelling, and show that the government's fiduciary obligations to the Aboriginal people in question have been respected by consulting with them, infringing their rights as little as possible in the circumstances, and paying them compensation for any expropriation. This has become known as the Sparrow 
justification test.

As Sparrow left open the issue of how Aboriginal rights are to be identified and defined, the Supreme Court was obliged to return to this question in 1996 in the Vander Peet, Gl.adstone, and N.T.C. Smokehouse cases (the Vander Peet trilogy)." We will focus our discussion on the Van der Peet case, as it laid down the test for identifying and defining Aboriginal rights that was applied in the other two decisions. That case involved charges laid against Dorothy Van der Peet, a member of the Sto:lo Nation in British Columbia, for unlawfully selling ten salmon that had been caught under the authority of an Indian food fish license. In defense, she claimed an Aboriginal right to sell fish.

The Chief Justice of Canada at the time, Antonio Lamer, wrote the majority judgment. In it, he created a test for identifying and defining Aboriginal rights that is commonly referred to as the "integral to the distinctive culture" test. In Lamer's words, "in order to be an aboriginal right an activity must be an element of a practice, custom or tradition integral to the distinctive culture of the aboriginal group claiming the right." ${ }^{5}$ Moreover, the time for determining whether a practice, custom, or tradition meets this test is the time prior to contact between the Aboriginal people in question and the European colonizers. Practices, customs, and traditions that arose as a result of contact do not qualify, as in Lamer's view they are not "aboriginal." In the case at hand, although the Sto:lo had traded with other Aboriginal nations and exchanged fish for other goods prior to European contact, Lamer found that exchange of salmon for money or other goods had not been an integral part of their distinctive culture. Dorothy Van der 
Peet therefore did not have an Aboriginal right to sell salmon, even in small quantities, as exchange of salmon had not been a defining feature of precontact Sto:lo society. Instead, it was incidental to the more primary activity of fishing for food and ceremonial purposes, and so was not sufficiently integral to their distinctive culture to be protected as an Aboriginal right.

Lamer's narrow, time-orientated approach to the identification and definition of Aboriginal rights has been severely criticized. The two women on the Supreme Court at the time, Justices McLachlin and L'Heureux-Dube, both wrote strong dissenting judgments. While accepting Lamer's statement of the appropriate test quoted above, McLachlin disagreed with the meaning he attached to "integral." For her, a practice is integral to an Aboriginal culture if it "is part of the unity of practices which together make up that culture. This suggests a very broad definition: anything which can be said to be part of the aboriginal culture would qualify as an aboriginal right protected by the Constitution Act, 1982."6 She also thought that Lamer's approach was too categorical, leading to an all-or-nothing result, and incorporated indeterminate subjective elements in identifying what is distinctive and central to a culture. She preferred an "empirical historic approach" that would allow judges to identify Aboriginal rights by asking: "ls this like the sort of thing which the law has recognized [as an Aboriginal right] in the past ?"7 Her goals seem to have been to avoid rigidity, and to ensure that Aboriginal peoples, in keeping with their traditions and cultures, continue to have access to the resources necessary to sustain their distinctive societies. In keeping with these goals, she also rejected Lamer's pre-contact time frame 
for identifying Aboriginal rights, suggesting instead that they should be based on traditional Aboriginal laws and customs whose roots, while historical, need not be traced to pre-contact times.

Justice L'Heureux-Dube was even more forceful in her dissent in Van der Peet. She characterized Chief Justice Lamer's precontact requirement as a "frozen right" approach that is inconsistent with Aboriginal perspectives, arbitrary, and unfair because it places an overly onerous burden of proof on the Aboriginal peoples. She preferred a "dynamic right" approach that would allow for the evolution of Aboriginal rights over time so they would "maintain contemporary relevance in relation to the needs of the natives as their practices, traditions and customs change and evolve with the overall society in which they live." ${ }^{18}$ As long as a practice, custom, or tradition was sufficiently fundamental to the Aboriginal culture in question "for a substantial continuous period of time"-which she suggested could range from twenty to fifty years-it would qualify for protection as an Aboriginal right. ${ }^{9}$ L'Heureux-Dube also criticized Lamer's narrow approach to the definition of Aboriginal rights. Instead of focusing on particular Aboriginal practices, traditions, and customs, as he did, she favored a generic approach that would define Aboriginal rights in a more general and abstract way. She wrote: "the aboriginal practices, traditions arid customs which form the core of the lives of native people and which provide them with a way and means of living as an organized society will fall within the scope of the constitutional protection under s.35(1)." ${ }^{10}$ Moreover, she viewed section 35(1) more broadly as protecting the distinctive cultures of the Aboriginal peoples rather than particular activities that are "manifestations" of those cultures: 
"Simply put, the emphasis would be on the significance of these activities to natives rather than on the activities themselves." 11

It was unclear from the Van der Peet decision whether Lamer's "integral to the distinctive culture" test would be applied to Aboriginal title to land. Commentators feared that it would, as the ChiefJustice had written in his majority judgment that "aboriginal title is the aspect of aboriginal rights related specifically to aboriginal claims to land."12 Six weeks later, in the Adams and Core decisions from Quebec, he elaborated on this connection between Aboriginal title and other Aboriginal rights by holding that Aboriginal rights, such as the fishing rights at issue in those cases, can exist independently of Aboriginal title. ${ }^{13}$ While those rights may be site-specific, they do not require the occupation and degree of use of land that is necessary to establish a claim to Aboriginal title.

The Adams and Cote decisions are significant for another reason as well. In both cases, Quebec argued that Aboriginal title to land could not exist in the province because the French law that had been in place before the conquest of New France by Britain in 1759-60 did not recognize Aboriginal land rights. Chief Justice Lamer refused to accept this argument. Even if the province's interpretation of precoriquest French law was correct (which Lamer found to be a matter of some doubt), he was unwilling to make the existence of Aboriginal title in various parts of Canada dependent upon which European power-France or Britain-happened to colonize an area first. If Quebec's argument were adopted, he said, it "would create an awkward patchwork of constitutional protection for aboriginal rights across the nation, depending 
upon the historical idiosyncracies of colonization over particular regions of the country." ${ }^{14} \mathrm{He}$ also found that it would risk "undermining the very purpose of section 35(1) by perpetuating the historical injustice suffered by aboriginal peoples at the hands of colonizers who failed to respect the distinctive cultures of preexisting Aboriginal societies." ${ }^{15}$ In this important respect, Adams and Core affirmed an earlier Supreme Court decision that the law of Aboriginal title is part of the federal common law that applies throughout the country. ${ }^{16}$

While the Adams and Cote decisions indicated that the Supreme Court saw important distinctions between Aboriginal title and other Aboriginal rights, the relevance of the Vander Peet approach to Aboriginal title remained uncertain. It was not at all clear whether the Court would apply the integral to the distinctive culture test in defining Aboriginal title. Resolution of this important issue had to await the Delgamuukw decision, handed down in December of 1997.

Defining and Proving Aboriginal Title to Land

The significance of Aboriginal title in Canada cannot be overestimated. Unlike in the United States, where most Indian lands were acquired by conquest or treaty during the course of colonization and westward expansion, in Canada conquest of the Aboriginal nations did not occur, and treaties involving land were limited for the most part to Ontario, the Prairie provinces, part of the Northwest Territories, and smaller portions of British Columbia. As a result, when Aboriginal title to land 
was accepted as a legal right by the Supreme Court in the Calder case in 1973, over half the country was still subject to Aboriginal title claims. ${ }^{17}$ Since then, some of these claims have been dealt with by modern land, claims agreements, most recently by the Nunavut, Yukon, and Nisga'a agreements. But large areas-particularly in the Atlantic Provinces, Quebec, and British Columbia remain subject to these claims. In those areas in particular, Aboriginal title has very significant implications for land ownership and resource development.

The issue of the content of Aboriginal title came squarely before the Supreme Court in the Delgamuukw case. ${ }^{18}$ That case involved claims by the Gitksan (also spelled Gitsan) and Wet'suwet'en nations in north, western British Columbia to ownership and jurisdiction over their traditional territories, an area almost as large as New Brunswick. The trial was the longest and most complex in Canadian history: it involved seventy, six witnesses, fifty three affidavits, and 9,200 documents, and took 374 days of court time. In a four hundred page judgment, Chief J ustice McEachem of the British Columbia Supreme Court dismissed the claims, but that decision was appealed up to the Supreme Court of Canada, which reversed the judgment and ordered a new trial, in part because McEachem had not dealt with the oral histories of the Gitksan and Wet'suwet'en in an appropriate way by according them the same kind of respect and weight that courts accord to written histories.

While not coming to any-Oecision on the merits of the case, the Supreme Court did lay down a number of principles to guide trial judges in 
Aboriginal title cases. In addition to providing more scope for the use of oral histories, the Court defined Aboriginal title, explained what is necessary to prove it, clarified the extent of federal authority over it, and addressed the issues of constitutional protection and infringement. Apart from the use of oral histories, we will discuss each of these matters in tum, paying particular attention to the Court's definition of Aboriginal title. Although the Court declined to deal with the claim to jurisdiction, which it characterized as a claim to self-government, we will nonetheless address this matter as well in the next section of this paper.

Prior to the Delgamuukw decision, there was disagreement over whether Aboriginal title is equivalent to ownership of land and thus includes natural resources such as timber and minerals, or is limited to the uses the particular Aboriginal nation made of the land in the past. Relying on the Vander Peet decision, the governments of Canada and British Columbia argued in Delgamuukw that Aboriginal title is limited to those past uses that meet the test of being "integral to the distinctive culture" of the claimants. The Gitksan and Wet'suwet'en, on the other hand, argued that Aboriginal title, although inalienable except by surrender to the Crown, is otherwise tantamount to fee simple ownership. Chief Justice Lamer, who wrote the principal judgment, did not accept either of these positions. In addition to being inalienable, he found that Aboriginal title differs from fee simple ownership in a number of significant respects. First, it has its source in occupation of land prior to assertion of sovereignty by the British Crown, whereas fee simple title arises afterwards. Secondly, Aboriginal title has an 
inherent limit that prevents the land from being used in ways that are inconsistent with the attachment to the land that gave rise to it in the first place. Finally, Aboriginal title is a collective right that is held communally by all the members of an Aboriginal nation. Because of these distinctive features, Aboriginal title is unlike any other common law property· interest-it is sui generis.

Chief Justice Lamer nonetheless came down on the side of the Gitksan and Wet'suwet'en on the vital issue of natural resources. Despite Aboriginal title's special features, he said that it is "the right to the land itself," which "encompasses the right to exclusive use and occupation of the land held pursuant to that title for a variety of purposes, which need not be aspects of those aboriginal practices, customs and traditions which are integral to distinctive aboriginal cultures." 19 He went on to hold specifically that Aboriginal title includes minerals, oil, and gas, even though exploitation of those resources might not have been a traditional use of the land. So the Vander Peet test does not apply to restrict the uses Aboriginal peoples may make of their lands, though Lamer did say that the connection with the land upon which Aboriginal title is based has to be "of central significance to their distinctive culture". ${ }^{20} \mathrm{He}$ hastened to add, however, that this need not be an explicit element of the test for Aboriginal title, as occupation of land and maintenance of a substantial connection with it would be sufficient in and of themselves to show that an Aboriginal nation's relationship with the land was integral to its distinctive culture.

This brings us to the matter of proof of Aboriginal title. Lamer said that 
Aboriginal title can be established by proof that the Aboriginal people in question were in exclusive occupation of the claimed lands at the time of Crown assertion of sovereignty. Exclusive occupation is required, he said, because the Aboriginal title it gives rise to is exclusive. However, he also envisaged joint Aboriginal title where two or more Aboriginal nations shared exclusive occupation. Lamer chose assertion of sovereignty rather than contact as the appropriate time for proving the requisite occupation because that is when Aboriginal title "arises out of prior occupation of land by the aboriginal peoples and out of the relationship between the common law and pre-existing systems of aboriginal law." ${ }^{21}$ It is a burden on the underlying title to land that the Crown acquires along with sovereignty, and so cannot predate sovereignty. In this respect, he distinguished Aboriginal title from other Aboriginal rights, which as we have seen must have pre-contact origins, because Aboriginal title depends simply on occupation of land, and so "does not raise the problem of distinguishing between distinctive, integral aboriginal practices, customs and traditions and those influenced or introduced by European contact."22 Also, he found the date of sovereignty to be more certain.

Though Lamer spoke of Crown "assertion" of sovereignty, he must have meant "acquisition," as that is when the Crown's underlying title to lands would vest. But it is unclear whether he intended to limit this to acquisition of sovereignty by the British Crown, or meant to include the French Crown as well. In parts of Eastern Canada, the difference between these two dates could be as much as 150 years, during which time considerable movement of Aboriginal populations, and hence changes in occupation of lands, took 
place. Also, in many areas of Canada the date of acquisition of European sovereignty is at least as uncertain as the date of contact, as sovereignty involves" murky legal questions as well as factual ones. Even more fundamentally, it might be asked why the onus is on Aboriginal peoples to prove their own title as against the European colonizers when we all know that they were here occupying lands when the newcomers arrived.

In addition to defining Aboriginal title and explaining how it can be proven, in Delgamuukw Chief Justice Lamer resolved an important issue concerning the division of powers between the federal and provincial governments. Under Canada's original 1867 Constitution, the federal government was given exclusive jurisdiction over "Indians, and Lands reserved for the Indians."23 However, it was unclear whether "Lands reserved" included Aboriginal title lands, or were limited to lands expressly reserved under the Royal Proclamation of 1763, treaties, or statutes such as the Indian Act. In Delgamuukw Lamer clarified this by deciding that Aboriginal title lands are indeed encompassed by the words "Lands reserved for the Indians." But he went even further by ruling that all Aboriginal rights, including Aboriginal title, are within the very core of this federal jurisdiction, which means that they are insulated from provincial laws by the constitutional doctrine of interjurisdictional immunity. ${ }^{24}$ As a result, Lamer held that ever since Confederation the provinces have lacked the authority to extinguish Aboriginal title.

We have seen that Lamer described Aboriginal title as "the right to the land itself ' and "the right to exclusive use and occupation." 25 These descriptive 
phrases clearly reveal that, despite its sui generis features, Aboriginal title is proprietary in nature. It therefore should be entitled to all the protection that English law, going back at least to Magna Carta in 1215, has traditionally accorded to property rights. Moreover, unlike other property rights in Canada, Aboriginal title is also constitutionally protected as an Aboriginal right by section 35( 1) of the Constitution Act, 1982. But despite these protections, when Lamer addressed the issue of infringement of Aboriginal title in Delgaтииkw he reached the startling conclusion that Aboriginal title may be justifiably infringed for a variety of purposes, including "the development of agriculture, forestry, mining, and hydroelectric power, the general economic development of the interior of British Columbia, protection of the environment or endangered species, the building of infrastructure and the settlement of foreign populations to support those aims." ${ }^{26}$ Most of these purposes fall within provincial jurisdiction, against which exclusive federal jurisdiction and the doctrine of interjurisdictional immunity, as we have seen, should protect Aboriginal title from infringement. But there is an even more fundamental reason to be disturbed by Lamer's list of justifiable purposes. The development of agriculture, forestry, and mining, for example, require not just government regulation of Aboriginal title lands, but a taking of those lands (or at least of the resources on or under them). As this looks more like expropriation than infringement, one is left wondering how this kind of treatment of the constitutional rights of the Aboriginal peoples can be justified, especially if the governments doing the taking (the provinces) have no jurisdiction over Aboriginal title. Moreover, as the Chief 
Justice probably did not have in mind publicly owned farms, forestry operations, and mines in this context, he must have envisaged the taking of Aboriginal lands for private as well as public purposes. Government taking of constitutionally protected property rights for the benefit of private interests is a violation of fundamental principles.

Lamer nonetheless tempered this governmental power over Aboriginal title lands by holding that consultation with the Aboriginal peoples affected has to take place before their rights are infringed. The degree of consultation depends on the extent of the infringement, and can amount to a need for outright consent where the infringement is especially serious. Also, as he said the government will ordinarily have to pay fair compensation, infringement is not cost free. As the compensation payable may outweigh the value of the infringement to the government, this last requirement might act as an effective practical impediment to widespread government interference with Aboriginal title.

In addition to Aboriginal title, the Delgamuukw case involved a claim by the Gitksan and Wet'suwet'en to jurisdiction, or a right of self-government, over their territories. As mentioned above, Chief J ustice Lamer declined to deal with this issue. He said: "The errors of fact made by the trial judge, and the resultant need for a new trial, make it impossible for this Court to determine whether the claim to self-government has been made out. Moreover, this is not the right case for the Court to lay down the legal principles to guide further litigation."27 However, in my view a right of selfgovernment is nonetheless implicit in the Delgamuukw decision. The next 
section of this paper will examine this issue.

An Aboriginal Right of Self-Government

So far the Supreme Court has dealt directly with a self-government claim only once, in the Pamajewon decision. ${ }^{28}$ That case involved a claim by the Shawanaga and Eagle Lake First Nations in Ontario that they have a right of self-government over their reserves that includes the right to regulate highstakes gambling. Delivering the principal judgment, Chief Justice Lamer assumed, without deciding, that the Aboriginal rights protected by section 35( 1) of the Constitution Act, 1982 include a right of self-government, but held that the Shawanaga and Eagle Lake First Nations had not established an Aboriginal right to engage in or regulate gambling. Applying the Van der Peet integral to the distinctive culture test, he found that, although the Ojibwa ancestors of these First Nations had gambled, that activity was not of central significance to their societies. Moreover, there was no evidence that they had regulated gambling. So their claim to self-government failed on the facts. The Pamajewon decision nonetheless left the door open for Aboriginal peoples to prove a right of self-government over activities that were integral to their distinctive cultures, if they could also establish that they had regulated those activities prior to European contact.

The Pamajewon decision has been criticized for, among other things, taking a narrow, fragmented approach to Aboriginal self-government. The Chief Justice refused to characterize the claim as being to "a broad right to 
manage the use of their reserve lands," as the Shawanaga and Eagle Lake First Nations wanted the Court to do. ${ }^{29}$ That, Lamer said, would "cast the Court's inquiry at a level of excessive generality." ${ }^{30} \mathrm{He}$ demanded greater specificity, thereby obliging Aboriginal peoples to prove their right of self-government on a piecemeal basis, activity by activity. Any possibility of establishing a broad right of self-government over their lands and peoples appeared to have been foreclosed by this decision.

Sixteen months later, the Supreme Court decided Delgamuukw. As we have seen, it declined to deal with self-government then. But Chief J ustice Lamer did make a very significant statement that has been taken to imply a right of self-government over Aboriginal title lands. After observing that Aboriginal title is held communally as "a collective right to land held by all members of an aboriginal nation," he said this: "Decisions with respect to that land are also made by that community." ${ }^{31}$ Now it is difficult to imagine how a community can make decisions about their land without some form of political organization that provides the means for collective decision-making. The communal nature of Aboriginal title, in and of itself, therefore seems to necessitate selfgovernment. ${ }^{32}$ Moreover, as other Aboriginal rights, such as hunting and fishing rights, are generally just as communal as Aboriginal title, the same analysis should apply to them as well. So instead of attempting to prove a right of self-government directly, Aboriginal peoples may have more success establishing other Aboriginal rights first, and then asserting that a right of self-government is entailed by the communal nature of those rights. 
Conclusions

The beginning of the twenty-first century shows a lot of promise for the Aboriginal peoples of Canada. Advances made by them in the political arena, starting with the entrenchment of their Aboriginal and treaty rights in the Constitution in 1982, have been matched by some solid victories in Canada's highest court. In what is undoubtedly its most signifi- cant Aboriginal-rights decision to date, the Supreme Court in Delgamuukw finally recognized that Aboriginal title to land includes a right to exclusive use and occupation that encompasses natural resources. Given the extent of unsettled Aboriginal title claims, especially in the Atlantic Provinces, Quebec, and British Columbia, the economic and political implications of this ruling are enormous. The issue of Aboriginal self-government has also been simmering ever since the constitutional conferences of the 1980 s, but outside of agreements such as those reached with the Inuit of Nunavut and the Nisga'a in British Columbia, it remains unresolved. Given, however, that a right of self-government probably underlies every other Aboriginal right, acknowledgement of its existence by the Supreme Court cannot be far off. 


\section{NOTES}

1. Note that, in principle if not in practice, the constitutional protection provided by section 35(1) makes Aboriginal rights in Canada more secure than Indian rights in the United States, as the latter are not constitutionally protected and so are subject to the plenary power of Congress.

2. See Kent McNeil, "The Decolonization of Canada: Moving Toward Recogni- tion of Aboriginal Governments," Western Legal History 7 (1994): 113-141.

3. R. v. Sparrow, [1990] 1 S.C.R. 1075.

4. R. v. Vander Peet, [1996] 2 S.C.R. 507; R. v. Gladstone, [1996] 2 S.C.R. 723; R. v. N.T.C. Smokehouse Ltd., [1996] 2 S.C.R. 672.

5. R. v. Vander Peet, supra note 4, para. 46.

6. Ibid., para. 256.

7. Ibid., para. 261 (emphasis in original).

8. Ibid., para. 172 .

9. Ibid., para. 175 (emphasis in original).

10. Ibid., para. 161.

11. hid., para. 157 (emphasis in original).

12. Ibid., para. 33.

13. R. v. Adams, (1996] 3 S.C.R. 101; R. v. Cote, (1996] 3 S.C.R. 139.

14. R. v. C6te, supra note 13, para. 53 .

15. Ibid.

16. Roberts v. Canada, [1989] 1 S.C.R. 322.

17. Calder v. Attorney-General of British Columbia, (1973) S.C.R. 313.

18. Delgamuukw t1. British Columbia, [1997) 3 S.C.R. 1010.

19. hid., para. 117, 140.

20. hid., para. 150, quoting from R. v. Adams, supra note 13, para. 26.

21. Delgamuиkw ti. British Columbia, supra note 18, para. 145.

22. Ibid.

23. Constitution Act, 1867,30 \& 31 Viet. (U.K.), c.3, s.91(24).

24. Where it applies, this llnctrine excludes the possibility of concurrent provin- cial jurisdiction. So where Aboriginal rights are concerned, it should prevent provincial laws of general application from affecting those rights.

25. See text accompanying note 19 , supra. 
26. Delgamuukw v. British Columbia, supra note 18,pra. 165

27. hid., para. 170.

28. R. v. Pamajewon, (1996) 2 S.C.R. 164.

29. Ibid., para. 27.

30. lhid.

31. Delgamuukw ti. British Columbia, supra note 18, para. 115.

32. For recent judicial acceptance of this argument, see Campbell v. British Columbia, [2000) 4C.N.L.R. 1 (B.C.S.C.). 